\title{
FIRST RECORD OF AN ANTHURID ISOPOD, CYATHURA UNIVAM SP. N., ON THE SOUTH AMERICAN CONTINENT
}

\author{
by \\ LAZARE BOTOSANEANU \\ Institute of Taxonomic Zoology (Zoölogisch Museum), University of Amsterdam, P.O. Box 20125, \\ 1000 HC Amsterdam, The Netherlands
}

\begin{abstract}
SUMMARY
Description of Cyathura univam sp. n. (Isopoda: Anthuridea), a depigmented and eyeless species from oligohaline cave water, at Mayorquines (Peninsula de Morocoy, Venezuela). This is the first species of the suborder to be found in South America. It is related to two stygobiont species, one from Curaçao and the other from Aruba.
\end{abstract}

\section{RÉSUMÉ}

Description de Cyathura univam sp. n. (Isopoda: Anthuridea), espèce dépigmentée et anophtalme d'une grotte à eau oligohaline de Mayorquines (Peninsula de Morocoy, Venezuela). Il s'agit de la première espèce du sous-ordre à être découverte en Amérique du Sud. Elle est apparentée à deux espèces stygobies, l'une de Curaçao et l'autre d'Aruba.

\section{INTRODUGTION}

Quite recently, Botosaneanu \& Stock (1982) published a report on the present status of our knowledge on the hypogean members of the genus Cyathura and other Anthuridea; not less than eight species of Cyathura were recognized from the peri-Caribbean zone (plus a single known species of the genus Curassanthura), but no stygobiont Cyathura or other Anthurid isopods were up to now discovered on the South American continent. During the 1982 Amsterdam Expedition to the Venezuelan Islands, additional sampling was performed in several localities on the mainland, during which a population of a species of Cyathura was found in

*) Report 29 is published in the same issue of this journal. a cave on the Morocoy Peninsula. The locality being rather close to the known localities of $C$. curassavica Stork, 1940 (Curaçao) and of C. hummelincki Botosaneanu \& Stock, 1982 (Aruba), it could not be excluded that the Venezuelan population belongs to one of these species; but, despite of some limitations generated by the absence of adult males in the material collected, it proved to be a distinctly new species, though probably closely related to the two abovementioned ones.

Cyathura univam sp. n. (figs. 1-19: $\odot$ holotype, generally left appendages represented)

Material and locality. - One adult $Q$ (holotype) and five immature specimens (paratypes). The appendages of the holotype (mostly of the left side) are dissected and mounted in Faure's medium on slides; the rest of the animal is preserved in alcohol $70 \%$. The paratypes are not dissected.

Amsterdam Expeditions to the West Indian Islands, sta. 82-512: Venezuela, Estado Falcón, Distrito Silva, Peninsula de Morocoy on the northern shores of the country, one of the Cuevas de Mayorquines (approximately $10^{\circ} 53^{\prime} 27^{\prime \prime} \mathrm{N} 68^{\circ} 14^{\prime} 49^{\prime \prime} \mathrm{W}$, the nearest more important locality on the coast being Chichiriviche); March 1-2, 1982; coll. L. Botosaneanu, N. Broodbakker, J. Notenboom and S. van Lieshout (Zoölogisch Museum Amsterdam coll. no. Is. 105.211 (holotype) and 105.212 (paratypes)).

This small peninsula is mainly composed of limestones, in contrast to the neighbouring zones, and just at its tip ("Mayorquines") a rather important system of vertical or horizontal caves has developed, some of which giving access to the phreatic water table. Some of these caves were inventoried in Anon. (1973a: 56-60) and in Anon. (1973b: 82-89). During the 1982 expedition, several caves were explored in Mayorquines, but, owing to the fact that 
the karst here is a true chaos, it was seldom possible to identify these caves with those inventoried in the two above-mentioned publications. For instance, the cave harbouring the presently described Cyathura is very probably one of those not yet inventoried by Venezuelan speleologists; certain is that its entrance is only some $60 \mathrm{~m}$ remote (in a S.S.E. direction) from the entrance of Cueva de Los Petroglifos, well-known for its Indian carvings.

The entrance of our cave is a few meters above sea level. A phreatic water table can be reached after a rather steep descent; the darkness here is complete; the water fills several rather deep pools, between large clastic blocks, and it also floods a diaclase a few dozens of metres long, with waters of a few meters in depth. The water is very clear, and despite of the proximity of the sea, oligohaline (chlorinity: $1024 \mathrm{mg} / \mathrm{l}$ ); the trophic resources are apparently very scanty (no vegetable material, very small amounts of bat guano). Cyathura univam sp. $\mathbf{n}$. was sampled together with the stygobiont amphipod Metaniphargus venezolanus Stock \& Botosaneanu, 1983. All the specimens collected were crawling on small sediment patches on the bottom, and the population is apparently not very important.

Description of the mature female (holotype). - In the following description, mainly features considered characteristic of the new species are emphasized. For a detailed description of the morphology of the stygobiont species of Cyathura, see Botosaneanu \& Stock (1982: 14-20).

Length, from tip of rostrum to tip of telson: $10 \mathrm{~mm}$. The specimen is completely devoid of pigment (white in alcohol) and of eyes or ocular pigment. Enormously developed oostegites are present on the pereionites III, IV and V.

First antennal peduncle segment 1 with a lateral excrescence which is almost as long as the segment, well demarcated but not forming a hump, and with a rather sharp edge (fig. 2). Second peduncle segment almost as long as the first, and characteristically widened distally (fig. 1). Third segment-with a welldifferentiated membranous zone at its endextremely long, definitely longer than the first or the second segments. Two-segmented flagellum, basal segment more than 5 times longer than the apical segment. Chaetotaxy without peculiarities, the basal peduncular segment apparently without certain setae present in related species $(C$. hummelincki Botosaneanu \& Stock, for instance).
Second antenna (fig. 3 ): segments 3,4 , and 5 very slender, the fourth distinctly longer than the third, the fifth distinctly longer than the fourth (length ratio of these three segments about $48: 65: 80$ ). The four segments of the flagellum are perfectly distinct.

Labrum (fig. 4), first maxilla (fig. 6), and second maxilla plus hypopharynx, apparently devoid of good distinctive characters.

Mandible (fig. 5) with palp characterized especially by its third segment being distinctly longer than the second (length ratio of the three segments about $20: 37: 47$ ); the third segment is slender with parallel edges, the short apical margin-bearing a compact row of 13 setae, only one of which is pectinated-being distinctly oblique. The second segment is also rather slender, and bears a single strong seta.

Maxilliped with a normal epipodite (not represented in fig. 7 , which gives a quite correct image of the other parts), without rudimentary endite between the first and second "free segments"; the most proximal of the spines of the second segment, as well as those of the distointernal and distoexternal angles, are not inserted on the edge, but on the ventral surface-though not far from the edge; except for these three spines there is a series of five smaller spines on the upper part of the internal margin, spines which are all almost equally distant (excepting the most proximal, which is also the smallest, and which is somewhat more distant from the next).

Gnathopod subchelate, as in all Cyathura; its basis is remarkably long (and slender), as long as the ischium (fig. 8); propodus extremely strong, with a palmar margin not only without any protuberance, but also almost straight (very slightly and evenly convex), with 22 small pectinated spines (fig. 9). Interestingly, the dactylus is extremely elongated, three times longer than the unguis (fig. 10).

Pereiopods II to VII similar, apparently without good distinctive characters, the distointernal spur of their propodi with a reduced number of "teeth" (3-5) in each of the two rows (figs. 11, 12).

The articulations between pleonites $\mathrm{I}$ to $\mathrm{V}$ 


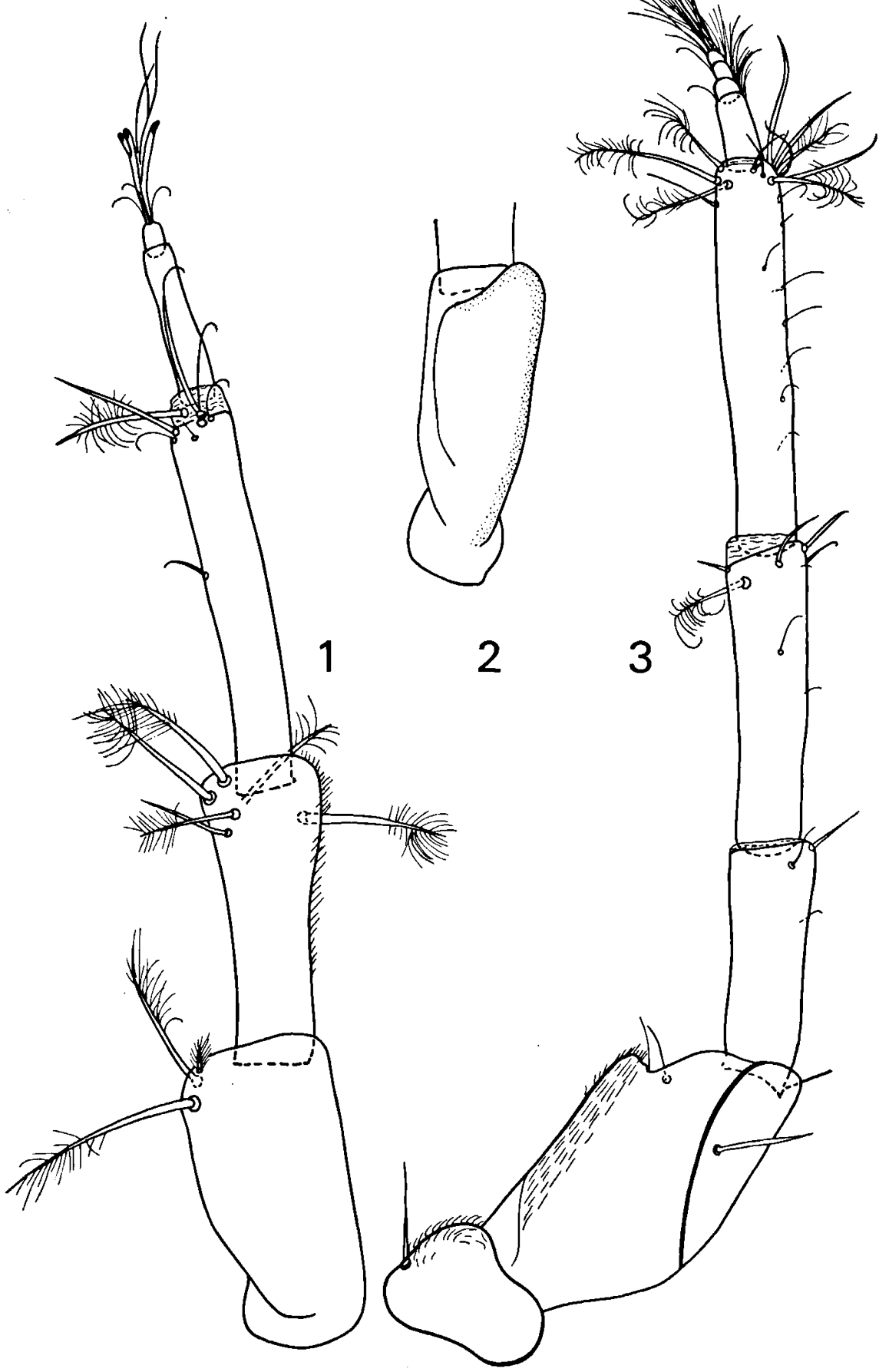

Figs. 1-3. Cyathura univam sp. n. ( $q$ holotype): 1 , antenna I; 2, basal segment of the peduncle of antenna I, in ventrolateral view; 3 , antenna II. 


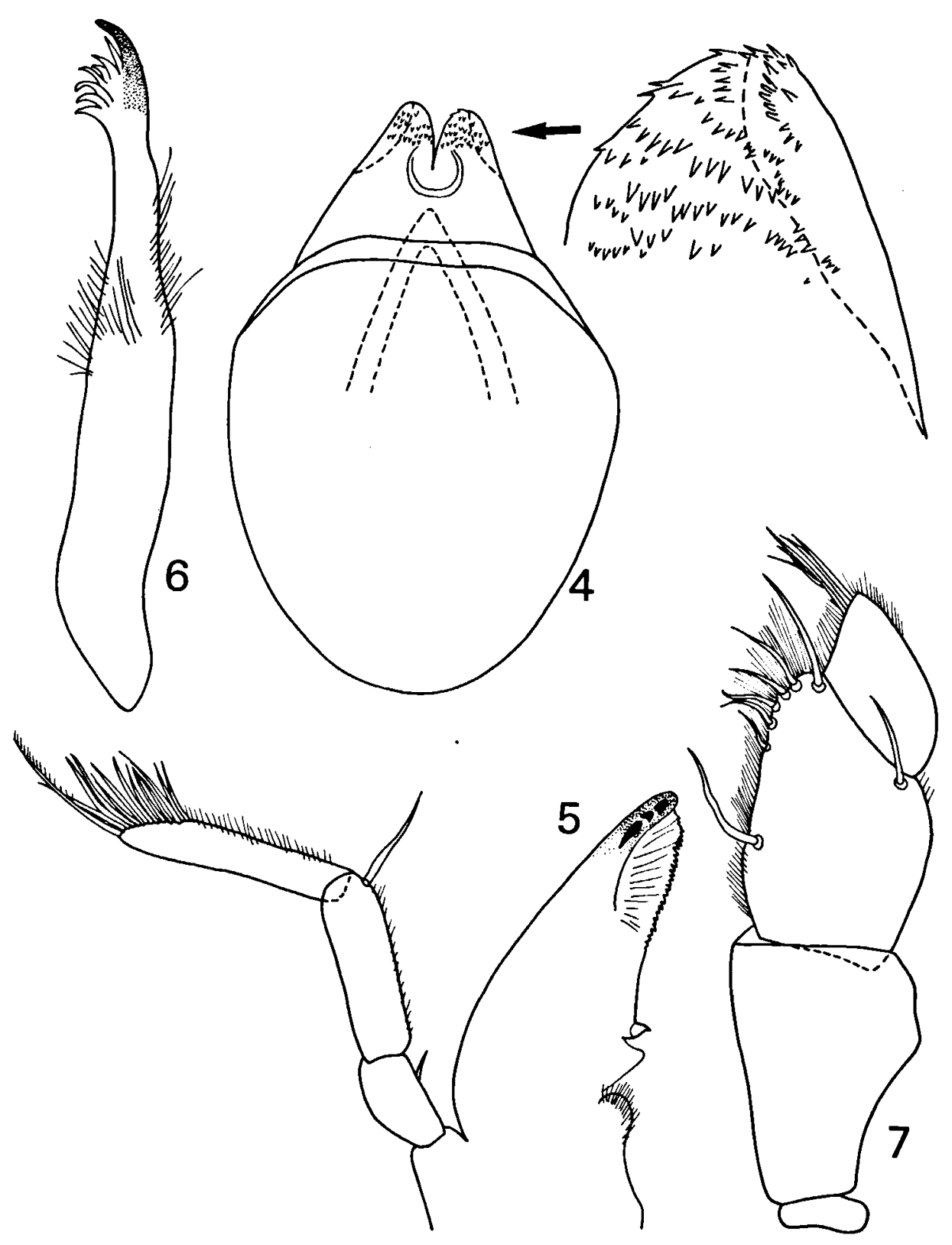

Figs. 4-7. Cyathura univam sp. n. ( $Q$ holotype): 4, dorsal view of labrum, with apical lobe strongly enlarged; 5 , mandible; 6, maxilla I, without internal lobe; 7 , maxilliped, without epipodite.

are clearly distinct, dorsally as well as laterally. Pleonite VI completely coalescent with the telson.

Pleopod I: external margin of exopodite regularly rounded, not angular; with some 13 pennate setae (fig. 13). Pleopods II to V (figs. 14-17) strongly differing from one another in the shape of their exopodites: very long and rather narrow in pleopod II, the exopodite becomes clearly shorter and wider in each of the following pleopods. Interesting feature: the exopodites of pleopods II to $\mathrm{V}$ show marked tendency towards biarticulation, as appears not only by a deep notch on the external margin (notch distally of which the fine ciliation of the edge abruptly disappears), but also by true in- 


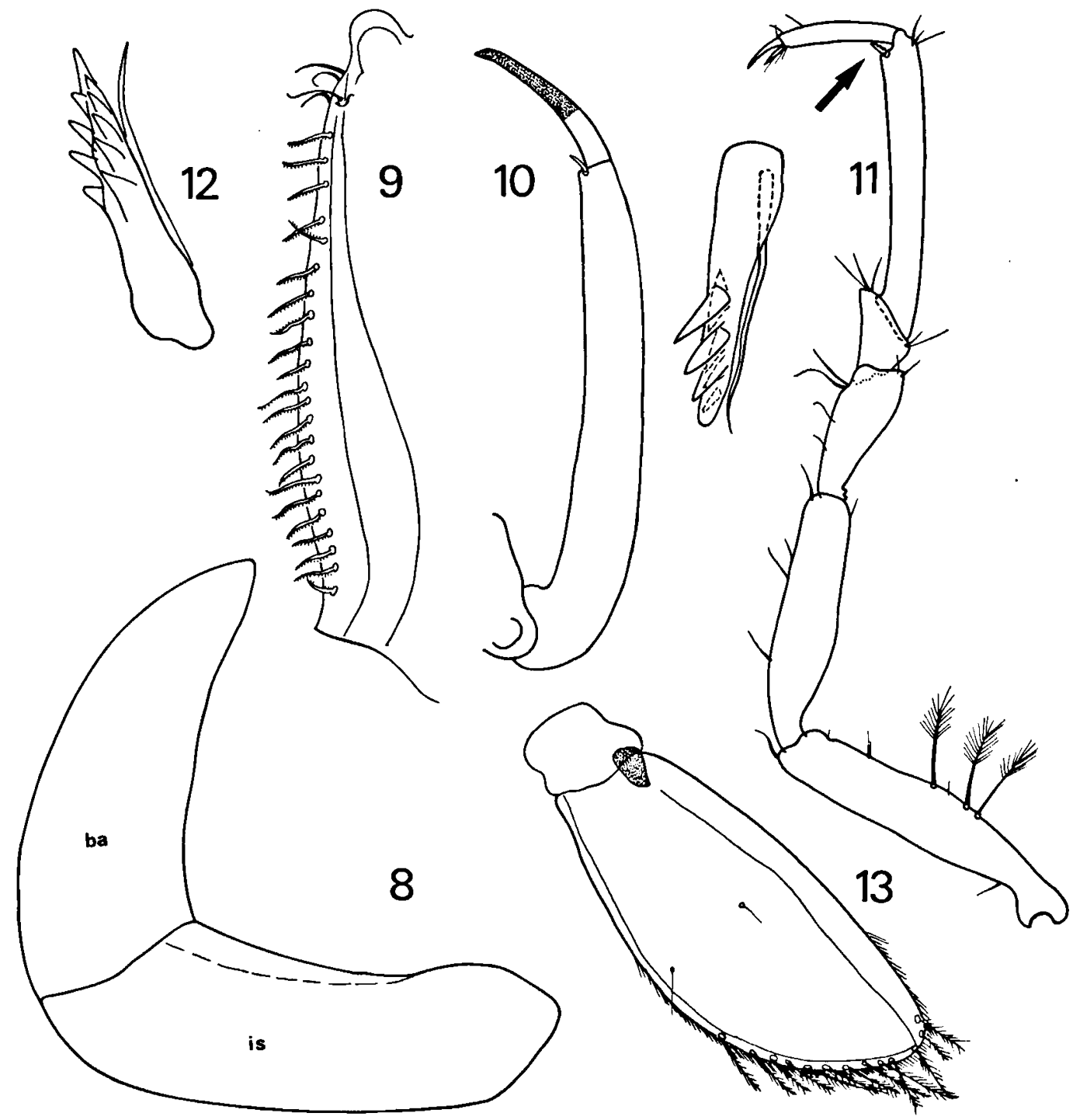

Figs. 8-13. Cyathura univam sp. n. ( 9 holotype): 8, basis (ba) and ischium (is) of right gnathopod, in lateral view; 9 , palmar margin of the propodus of the gnathopod; 10 , dactylus and unguis of gnathopod; 11, pereiopod IV, and its distointernal propodal spur strongly enlarged; 12, distointernal spur of propodus of pereiopod VII; 13, pleopod I, in dorsal view.

tersegmental lines, which are complete at least in pleopod II (they seem to be incomplete in the following pleopods, but this is not quite sure).

Uropod with a regularly oval, quite elongate endopodite (ratio length endopodite/length sympodite about $5.1: 7.7$ ), and with a very narrow exopodite, which is not at all flattened and which may be called baculiform, or, even better, considered as a strong spur, with maximal width at its base, where it is 4.5 times narrower than the sympodite in its middle. The chaetotaxy of the uropod is very completely represented in fig. 18.

Telson (fig. 19) a strongly developed shield, whose edges are very regularly and almost insensibly converging towards a broadly rounded end, central part of which is a slightly wavy, shallow sinus; in the holotype, the apical setae are represented only by a pair of very short elements, inserted on both sides of the flat bot- 


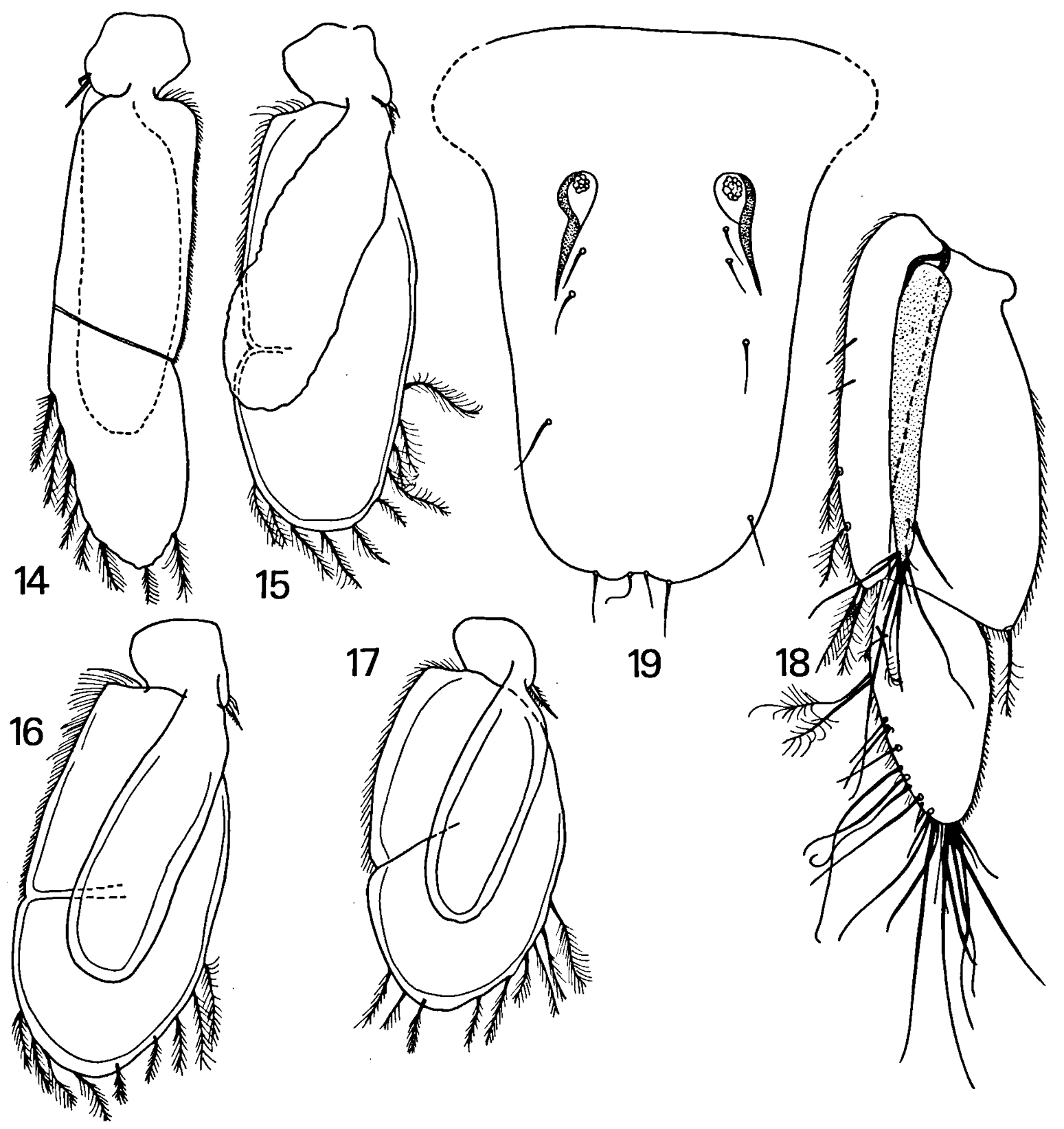

Figs. 14-19. Cyathura univam sp. n. ( $Q$ holotype): 14-17, pleopods II-V (all in dorsal view, except for pleopod II which i: represented in ventral view; all more enlarged than pleopod I-fig. 13); 18, uropod; 19, telson.

tom of the shallow sinus mentioned before (the other two setae represented in fig. 19 at the telson's apex do not belong to the apical tuft!).

The immature specimens (paratypes). The length of the five specimens is $3.75,4,4.4$, 4.7 , and $4.75 \mathrm{~mm}$. All of them are completely devoid of pigment and eyes. The pleonal segmentation is well marked in all specimens. In one of the smallest specimens both pereiopods VII are absent; they are rudimentarily developed in three other specimens; in the largest of the five specimens pereiopod VII looks more or less completely developed. There is no trace of an appendix masculina even in the largest of these specimens. A superficial 
examination showed that several distinctive features of the new species are visible even in the immatures (for instance: the very elongated dactylus of the gnathopod; the minute apical setae of the telson), whereas the uropodal exopodite seems to be-proportionally-somewhat less distinctly baculiform, the characters of pleopods II-V are not in their definitive state, and the apical sinus of the telson is deeper and more rounded).

Derivatio nominis. - The name of the new species is coined after Universiteit van Amsterdam, as a testimony of the author's gratitude towards this institution.

Discussion. - The absence of mature males in the available material makes it not easy to establish the affinities of the new species, as it is the appendix masculina which offers the best characters for such considerations. Nevertheless, there is rather good evidence that $C$. univam sp. n. is related to C. curassavica Stork, and especially to $C$. hummelincki Botosaneanu \& Stock, the first from Curaçao, the second from Aruba. In the female, characters suggesting a relationship to $C$. hummelincki, and sometimes to C. curassavica too, are: the shape of the lateral excrescence of the first peduncular segment, and the exceptional development of the third segment of the peduncle of the first antenna, in the final stage of development; the elongated, gracile, segments of the mandibular palp; the identical number of spines (8) on the penultimate segment of the maxilliped; the very slightly prominent palmar edge of the gnathopodal propodus, provided with a large number of pectinate spines; the apically rounded telson, with the apical setae inserted on the bottom of a sinus and (in some specimens at least!) the very strongly reduced length of these setae.

But, even in the absence of the mature male, a large number of characters show, beyond any doubt, that we have here a distinct species. The most significant of these are as follows: the new species is large, larger even than $C$. curassavica and hummelincki which are already large species; the second peduncular segment of the first antenna, very long and apically widened; very long and slender third, fourth and fifth segments of the peduncle of the second antenna; mandibular palp in which the third segment is distinctly longer than the second, apical edge obliquely cut and short, offering insertion to all 13 apical setae, only one of which is pectinate; the arrangement of the spines on the second "free segment" of the maxilliped, which is slightly different from that found, for instance, in C. hummelincki; the extremely elongate dactylus of the gnathopod, which is 3 times longer than the unguis, and thus comparatively longer than in any other known stygobiont Cyathura (in C. hummelincki and C. curassavica it is about 1.5 times longer than the unguis); distointernal spur on the propodus of pereiopods II-VII, with a number of "teeth" which is much lower than in C. hummelincki; pleopod I with external edge of exopodite regularly rounded, not at all angular; uropod with a regularly oval and quite elongated endopodite, and with a narrow, spurlike, exopodite; telson with edges very regularly and almost insensibly converging towards a broadly rounded end.

To these, a few other characters could be added, somewhat less sure, owing to the fact that they were underestimated or even neglected in previous studies on Cyathura, including that by Botosaneanu \& Stock (1982): there are only three setae, all pennate, at the apicolateral angle of the first peduncular segment of antenna I (two more, non pennate, in C. hummelincki); the slender basis of the gnathopod, as long as the ischium, is a peculiarity distinguishing the new species at least from most of the other species of Cyathura, where it is distinctly shorter and stouter. The exopodites of pleopods II-V, markedly differing from one another by their shape, and with a very clear tendency towards segmentation, are possibly an interesting distinctive character as well, but unfortunately comparisons are presently difficult to perform.

Finally, it should be emphasized that there is a distinct similarity, from all points of view, between the situation of the new Cyathura and 
that of Metaniphargus venezolanus Stock \& Botosaneanu, 1983, discovered in its company: without doubt, good examples of (rapid) speciation, to be explained in terms of the "regression model" theory (cf. Stock, 1981).

\section{ACKNOWLEDGEMENTS}

The fieldwork on which the present study is based has been financially supported by the Amsterdamse Universiteitsvereniging, the Treub Maatschappij (Utrecht), the Beijerinck Popping Fonds, Amsterdam, and the University of Amsterdam. The organization of the fieldwork in Venezuela has greatly benefited from support rendered by H. M. Embassy of the Netherlands, Caracas, in particular by Dr. Ir. Th. P. M. de Wit, Agricultural Attaché.

Useful information on the caves at Mayorquines, obtained from the Sociedad Venezolana de Espeleologia (Caracas) and in particular from Dr. Franco Urbani and Dr. Omar Linares, is gratefully acknowledged.

\section{REFERENCES}

Anon., 1973a. Catastro espeleologico de Venezuela. Boln. Soc. venez. Espeleol., 4 (1): 39-88.

Anon., 1973b. Catastro espeleologico de Venezuela, 1: 1-151 (Sociedad Venezolana de Espeleologia, Caracas).

Botosaneanu, L. * J. H. Stock, 1982. Amsterdam Expeditions to the West Indian Islands, Report 17. Les Cyathura stygobies (Isopoda, Anthuridea) et surtout celles des Grandes et des Petites Antilles. Bijdr. Dierk., 52 (1): 13-42.

Sтоск, J. H., 1981. L'origine géologique des îles des Indes Occidentales en relation avec la dispersion de quelques Malacostracés stygobionts. Géobios (Lyon), 14 (2): 219-227.

Stock, J. H. \& L. Botosaneanu, 1983. Amsterdam Expeditions to the West Indian Islands, Report 26. Première découverte d'Amphipodes Gammaridae du groupement des Hadziides dans des eaux souterraines de l'Amérique du Sud: description de Metaniphargus venezolanus sp. n. Bijdr. Dierk., 53 (1): 158-164. 